\title{
PENERAPAN METODE ILLINOIS PADA PENENTUAN BESAR CADANGAN PREMI ASURANSI JIWA BERSAMA DWIGUNA
}

\author{
Irma Friyanti, Neva Satyahadewi, Hendra Perdana
}

\begin{abstract}
INTISARI
Asuransi jiwa dwiguna merupakan perpaduan antara asuransi jiwa berjangka dan asuransi jiwa seumur hidup. Dalam asuransi jiwa dwiguna, peserta asuransi baik meninggal dunia maupun bertahan hidup akan dibayarkan uang pertanggungan. Sebagian dari premi yang diterima oleh perusahaan harus dicadangkan sebagai cadangan premi, sehingga bila dimasa yang akan datang terjadi klaim maka perusahaan tidak kesulitan membayarnya. Penelitian ini bertujuan untuk menentukan besarnya cadangan yang diperoleh dengan menggunakan metode Illinois yang merupakan perluasan dari cadangan prospektif. Data yang digunakan dalam penelitian ini adalah data Tabel Mortalita Indonesia 2011 untuk sepasang suami istri dengan usia suami 30 tahun dan usia istri 27 tahun, lama masa pertanggungan asuransi 25 tahun, lama masa pembayaran premi 22 tahun, tingkat suku bunga 2,5\% dan besar santunan yang akan diterima sebesar Rp200.000.000,-. Nilai cadangan yang dihasilkan untuk tahun pertama sebesar Rp451.799,- dan akan semakin besar setiap tahunnya selama masa pertanggungan sehingga nilai cadangan akan sama dengan santunan yang diterima oleh tertanggung ketika masa periode berakhir.
\end{abstract}

Kata Kunci: Asuransi Dwiguna, Cadangan Premi, Metode Illinois

\section{PENDAHULUAN}

Pada zaman sekarang perlindungan akan jaminan hidup sangat diperlukan, terutama tentang meminimalisir kerugian dalam hidup tersebut. Meminimalisir kerugian dalam hidup itu bisa diatasi dengan asuransi. Salah satu jenis asuransi adalah asuransi jiwa. Asuransi jiwa adalah suatu upaya perlindungan yang diberikan oleh pihak penanggung terhadap risiko pada jiwa tertanggung yang akan timbul dari suatu peristiwa yang tidak dapat diprediksi seperti kematian, kecelakaan, atau kehilangan kemampuan dalam memperoleh penghasilan [1]. Asuransi jiwa dibagi menjadi tiga jenis, yaitu asuransi jiwa berjangka, asuransi jiwa seumur hidup, dan asuransi jiwa dwiguna (endowment). Asuransi jiwa dwiguna merupakan perpaduan antara asuransi jiwa berjangka dan asuransi jiwa seumur hidup [2].

Asuransi jiwa tidak hanya menyediakan perlindungan tertanggung untuk satu orang saja (single life), namun juga menyediakan perlindungan untuk dua orang atau lebih (multiple life). Perbedaan antara asuransi jiwa perorangan dengan asuransi jiwa bersama terletak pada peserta yang mengikuti asuransi tersebut. Pada asuransi jiwa perorangan, perusahaan asuransi memberikan perlindungan untuk satu orang (tunggal) tertanggung, sedangkan jumlah tertanggung pada pada asuransi jiwa bersama lebih dari satu orang. Salah satu produk asuransi jiwa bersama adalah asuransi status hidup gabungan untuk asuransi bersama (joint life insurance) [2].

Dalam mengikuti program asuransi jiwa, terdapat serangkaian pembayaran yang dilakukan oleh peserta asuransi yang disebut premi. Premi yang diterima perusahaan tidak hanya menjadi profit perusahaan tetapi sebagian juga merupakan kewajiban perusahaan dimasa mendatang. Sebagian dari premi harus dicadangkan perusahaan sebagai cadangan premi sehingga bila dimasa yang akan datang terjadi klaim maka perusahaan tidak kesulitan membayarnya. Cadangan premi merupakan besarnya uang yang ada pada perusahaan dalam jangka waktu pertanggungan. Cadangan premi tersebut berasal dari selisih nilai tunai premi dan nilai uang pertanggungan [1].

Perhitungan cadangan premi tersebut dilakukan melalui metode perhitungan matematika aktuaria yaitu menggunakan metode prospektif dan retrospektif. Metode cadangan retrospektif adalah metode 
perhitungan cadangan berdasarkan pendapatan waktu yang lalu sampai saat dilakukan perhitungan cadangan dikurangi dengan jumlah pengeluaran di waktu yang lampau untuk pemegang polis. Sedangkan metode cadangan prospektif didefinisikan sebagai selisih antara nilai sekarang (present value) dari benefit atau manfaat yang akan diterima dengan nilai sekarang dari premi bersih yang akan datang sesuai dengan anuitas yang telah ditentukan pada saat polis disetujui [2].

Penelitian ini mengkaji salah satu metode cadangan premi asuransi, yaitu metode Illinois. Metode tersebut merupakan bagian dari metode prospektif dengan membatasi biaya yang dibebankan pada peserta asuransi dengan batasan 20 tahun pembayaran. Penelitian ini bertujuan untuk mengkaji cadangan premi dengan menggunakan metode Illinois dan diberikan aplikasi numerik cadangan pada asuransi jiwa bersama dwiguna. Tingkat suku bunga yang digunakan yaitu $2.5 \%$, mengunakan Tabel Mortalita Indonesia (TMI) 2011.

Penentuan cadangan Illinois dimulai dari menentukan usia tertanggung $x$ tahun dan $y$ tahun, lama masa pertanggungan selama $n$ tahun, lama masa pembayaran $m$ tahun, dan besar santunan yang dipilih. Selanjutnya, menghitung nilai asuransi bersama, menghitung nilai anuitas bersama dan menghitung nilai premi tahunan bersama untuk produk asuransi jiwa bersama dwiguna. Setelah itu, ditentukanlah nilai cadangan premi metode Illinois dari sebuah perusahaan.

\section{ASURANSI JIWA DWIGUNA}

Asuransi dwiguna adalah suatu jenis asuransi yang merupakan gabungan dari asuransi dwiguna murni (pure endowment) $n$ tahun dan asuransi berjangka $n$ tahun. Polis asuransi jiwa dwiguna menjanjikan pembayaran sejumlah uang bila terjadi kematian dalam jangka waktu atau bila tertanggung hidup diakhir jangka waktu. Pada penelitian ini asuransi jiwa yang digunakan yaitu asuransi jiwa dwiguna bersama untuk kasus dua orang tertanggung, yaitu:

$$
\begin{aligned}
A_{x, y: n} & =A_{x, y: n}+A_{x, y: n} \cdot \overline{1} \\
& =\left(\sum_{t=0}^{n-1} v^{t+1}{ }_{t} p_{x, y} q_{x+t, y+t}\right)+v^{n}{ }_{n} p_{x, y}
\end{aligned}
$$

dimana:

$n \quad=$ lama masa periode pertanggungan asuransi

$k \quad=$ sisa masa pertanggungan asuransi

$v^{t+1} \quad=$ faktor diskonto periode $(t+1)$

${ }_{t} p_{x, y}=$ peluang seseorang berusia $x$ tahun dan $y$ tahun akan hidup sampai $t$ tahun

$q_{x+t, y+t}=$ peluang seseorang berusia $(x+t)$ tahun dan $(y+t)$ akan meninggal

$v^{n} \quad=$ faktor diskonto pada periode $n$ tahun

${ }_{n} p_{x, y}=$ peluang seseorang berusia $x$ tahun dan $y$ tahun akan hidup sampai $n$ tahun

$A_{x, y: n}=$ asuransi dwiguna murni (pure endowment) $n$ tahun

$A_{x, y: \frac{1}{n}}=$ asuransi berjangka $n$ tahun

\section{TINGKAT SUKU BUNGA}

Tingkat suku bunga terdiri atas dua jenis, yaitu bunga tunggal dan bunga majemuk. Bunga tunggal atau yang sering disebut dengan bunga sederhana, dihitung berdasarkan pada perbandingan pokok dengan jangka waktu investasinya. Sedangkan bunga majemuk merupakan perhitungan bunga yang besar pokok dan jangka investasinya ialah jumlahan antara besar pokok sebelumnya dengan besar bunga yang diperoleh [1]. 
Tingkat suku bunga (i) adalah rasio dari besar bunga yang diperoleh selama periode tertentu terhadap besarnya nilai pokok pada saat awal periode [4]. Nilai sekarang adalah investasi sebesar 1 yang akan terakumulasi menjadi $(i+1)$ pada akhir periode ke 1 [1]. Nilai sekarang pada periode $n$ juga bisa disebut dengan faktor diskonto yang dinotasikan dengan $v^{n}$, yaitu:

$$
v^{n}=\frac{1}{(i+1)^{n}}
$$

\section{ANUITAS JIWA}

Anuitas adalah suatu deretan pembayaran, biasanya dalam jumlah yang sama untuk suatu jangka waktu dan lama tertentu secara berkelanjutan. Berdasarkan cara pembayarannya, anuitas hidup dibedakan menjadi dua macam yaitu anuitas diskret dan anuitas kontinu. Serangkaian pembayaran anuitas ini dapat dilakukan dengan dua cara yaitu, dengan cara berjangka dan seumur hidup [1]. Pada penelitian ini anuitas jiwa yang digunakan dalam perhitungan yaitu anuitas jiwa diskret awal berjangka $n$ tahun dengan dua orang tertanggung. Rumus anuitas jiwa ini yaitu:

$$
\ddot{a}_{x, y: n}=\sum_{t=0}^{n-1} v_{t}^{t} p_{x, y}
$$

\section{PREMI}

Premi merupakan sejumlah uang yang wajib dibayarkan oleh pemegang polis kepada perusahaan asuransi dengan cara yang telah ditentukan dan sekaligus menjadi syarat diperolehnya perlindungan asuransi [5]. Secara umum terdapat dua jenis premi, yaitu premi bersih (netto) dan premi kotor (bruto). Premi netto adalah premi yang perhitungannya hanya menggunakan perkiraan tingkat mortalita dan tingkat suku bunga. Premi netto untuk asuransi jiwa dwiguna dimana tertanggung berusia $x$ tahun dan $y$ tahun, masa pertanggungan $n$ tahun dan pembayaran premi di awal tahun selama $m$ tahun dengan uang santunan sebesar $R$ dinyatakan dengan:

$$
\begin{aligned}
{ }_{m} P_{x, y: n} & =R \times \frac{A_{x, y \cdot n}}{\ddot{a}_{x, y: m}} \\
& =R \times \frac{\left[\left(\sum_{t=0}^{n-1} v^{t+1}{ }_{t} p_{x, y} q_{x+t, y+t}\right)+v^{n}{ }_{n} p_{x, y}\right]}{\sum_{t=0}^{m-1} v^{t}{ }_{t} p_{x, y}}
\end{aligned}
$$

\section{CADANGAN PREMI ASURANSI}

Pada dunia perasuransian, cadangan dalam asuransi jiwa merupakan suatu dana yang disisihkan untuk digunakan dalam keadaan darurat. Cadangan premi bukan merupakan aset atau bagian kekayaan perusahaan, melainkan kewajiban perusahaan atau hutang perusahaan kepada para pemegang polis karena sebagian dana perusahaan merupakan pemilik pemegang polis [6]. Perhitungan cadangan premi dapat dilakukan diantaranya menggunakan metode prospektif. Metode cadangan prospektif adalah perhitungan cadangan yang berorientasi pada pengeluaran di waktu yang akan datang. Perhitungan cadangan berdasarkan nilai sekarang dari semua pengeluaran di waktu yang akan datang, dikurangi dengan nilai sekarang total pendapatan di waktu yang akan datang untuk setiap pemegang polis [1].

Rumus cadangan premi pada tahun ke- $t$, untuk premi asuransi jiwa dwiguna dimana tertanggung berusia $x$, masa pertanggungan asuransi $n$ tahun dan pembayaran premi di awal tahun selama $m$ tahun, dengan metode prospektif yaitu:

$$
{ }_{t}^{m} V_{x: n}=A_{x+t: \overline{n-t} \mid}-{ }_{m} P_{x: n} \ddot{a}_{x+t: \overline{m-t}}
$$


Berdasarkan definisi cadangan prospektif, simbol beserta rumus untuk cadangan prospektif diskret akan dituliskan pada Tabel 1.

Tabel 1 Cadangan Prospektif Diskret

\begin{tabular}{|c|c|c|c|}
\hline Jenis Asuransi Jiwa & $\begin{array}{c}\text { Notasi } \\
\text { Aktuaria } \\
\text { Internasional }\end{array}$ & \multicolumn{2}{|c|}{ Persamaan Prospektif } \\
\hline $\begin{array}{l}\text { Dwiguna berjangka } \\
n \text { tahun }\end{array}$ & ${ }_{t} V\left(A_{x: n}\right)$ & $\left\{\begin{array}{c}A_{x+t: \overline{n-t}}-P\left(A_{x: n}\right) \ddot{a}_{x+t \overline{n-t}} \\
1\end{array}\right.$ & $\begin{array}{l}t<n \\
t=n\end{array}$ \\
\hline $\begin{array}{l}\text { Dwiguna berjangka } \\
n \text { tahun, pembayaran } m \\
\text { tahun }\end{array}$ & ${ }_{t}^{m} V\left(A_{x: n}\right)$ & $\left\{\begin{array}{c}A_{x+t: \overline{n-t}}-{ }_{m} P\left(A_{x: \bar{n}}\right) \ddot{a}_{x+t: \overline{m-t}} \\
A_{x+t: \overline{n-t}} \\
1\end{array}\right.$ & $\begin{array}{c}t \leq m \\
m<t<n \\
t=n\end{array}$ \\
\hline
\end{tabular}

\section{CADANGAN ILLINOIS}

Cadangan Illinois merupakan perluasan dari cadangan prospektif dimana pihak perusahaan membatasi biaya yang dibebankan pada peserta asuransi dengan batasan 20 tahun pembayaran. Dalam metode Illinois, terdapat beberapa nilai premi bersih yakni $\alpha$ (premi bersih untuk tahun pertama), $\beta$ (premi bersih untuk 19 tahun berikutnya), dan $P$ (premi bersih tahunan). Perumusan dari pernyataan di atas dapat diilustrasikan sebagai berikut:

$$
\alpha+\beta \ddot{\alpha}_{x, y: \overline{n-1}}=P \ddot{\alpha}_{x, y: n}
$$

Cadangan Illinois dinotasikan sebagai ${ }_{t}^{m} V_{x, y: n}$ dan selanjutnya $\beta$ dinotasikan sebagai premi bersih untuk 19 tahun berikutnya, sehingga untuk besar cadangan dari tahun ke $t$ sampai ke $n$ adalah:

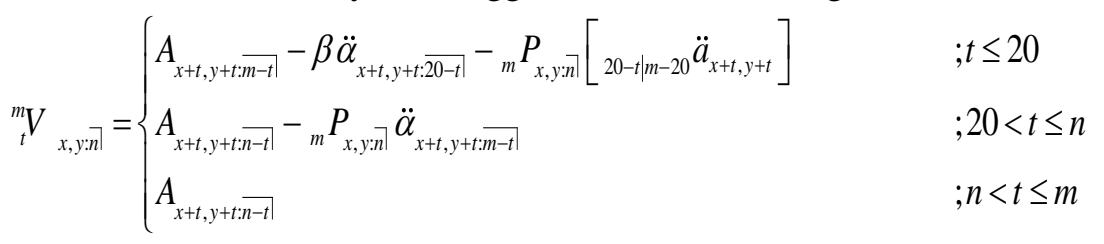

\section{APLIKASI NUMERIK}

Pada penelitian ini diberikan studi kasus sebagai simulasi perhitungan cadangan premi asuransi untuk produk asuransi jiwa bersama dwiguna dengan program yang akan digunakan adalah Microsoft Excel. Contoh kasus: sepasang suami istri yang baru menikah tahun 2018 dengan usia suami 30 tahun dan usia istri 27 tahun hendak mengikuti program asuransi jiwa bersama (joint life). Jenis asuransi jiwa yang dipilih adalah asuransi jiwa dwiguna dengan masa pertanggungan selama 25 tahun. Jangka waktu pembayaran premi selama 22 tahun dan pembayaran premi dilakukan setiap awal bulan. Besar santunan yang akan diterima ahli waris ketika salah satu tertanggung meninggal dunia adalah Rp100.000.000 sehingga total santunan adalah Rp200.000.000,--

Pada Tabel 2 pada tahun pertama cadangan premi yang disiapkan oleh perusahaan sebesar Rp451.799,- dan akan terus meningkat untuk setiap tahunnya sampai akhir masa pertanggungan. Pada masa pertanggungan asuransi jiwa dwiguna berakhir, pihak asuransi telah siap untuk memberikan santunan sebesar yang dijanjikan kepada tertanggung.

Tabel 2 Nilai Cadangan Premi Menggunakan Metode Illinois

\begin{tabular}{llllll}
\hline $\boldsymbol{t}$ & ${ }_{t}^{22} V_{30,27: 25}$ & $\boldsymbol{t}$ & ${ }_{t}^{22} V_{30,27: 25}$ & $\boldsymbol{t}$ & ${ }_{\boldsymbol{t}}^{22} V_{30,27: 25}$ \\
\hline 1 & $\mathrm{Rp} 451.799$ & 10 & $\mathrm{Rp} 67.263 .026$ & 19 & $\mathrm{Rp} 150.046 .067$ \\
2 & $\mathrm{Rp7.170.186}$ & 11 & $\mathrm{Rp} 75.603 .783$ & 20 & $\mathrm{Rp} 160.092 .356$ \\
\hline
\end{tabular}


Tabel 2 Nilai Cadangan Premi Menggunakan Metode Illinois(lanjutan)

\begin{tabular}{lccccc}
\hline $\boldsymbol{T}$ & ${ }_{t}^{22} V_{30,27: 25}$ & $\boldsymbol{t}$ & ${ }_{t}^{22} V_{30,27: \overline{25}}$ & $\boldsymbol{t}$ & ${ }_{t} V_{30,27: \overline{25}}$ \\
\hline 3 & $\mathrm{Rp} 14.054 .193$ & 12 & $\mathrm{Rp} 84.137 .395$ & 21 & $\mathrm{Rp} 164.637 .320$ \\
4 & $\mathrm{Rp} .21 .112 .605$ & 13 & $\mathrm{Rp} 92.873 .509$ & 22 & $\mathrm{Rp} 175.089 .432$ \\
5 & $\mathrm{Rp} 28.348 .883$ & 14 & $\mathrm{Rp} 101.822 .501$ & 23 & $\mathrm{Rp} 185.881 .808$ \\
6 & $\mathrm{Rp} 35.763 .539$ & 15 & $\mathrm{Rp} 110.991 .067$ & 24 & $\mathrm{Rp} 190.422 .022$ \\
7 & $\mathrm{Rp53.359.372}$ & 16 & $\mathrm{Rp} 120.385 .617$ & 25 & $\mathrm{Rp} 200.000 .000$ \\
8 & $\mathrm{Rp} 51.139 .773$ & 17 & $\mathrm{Rp} 130.016 .327$ & & \\
9 & $\mathrm{Rp59.108.754}$ & 18 & $\mathrm{Rp} 139.897 .607$ & & \\
\hline
\end{tabular}

\section{CADANGAN PREMI METODE ILLINOIS DENGAN SUKU BUNGA BERVARIASI}

Berdasarkan studi kasus dilakukan perhitungan dengan menambahkan tingkat suku bunga yang berbeda, diperoleh hasil nilai cadangan premi metode Illinois dengan suku bunga yang berbeda dapat dilihat pada Tabel 3 berikut:

Tabel 3 Nilai Cadangan Premi Menggunakan Metode Illinois dengan Suku Bunga Bervariasi

\begin{tabular}{|c|c|c|c|c|c|}
\hline No. & $\mathrm{i}=1 \%$ & $\mathrm{i}=1.5 \%$ & $\mathrm{i}=\mathbf{2 \%}$ & $\mathrm{i}=\mathbf{3 \%}$ & $\mathrm{i}=3.5 \%$ \\
\hline 1 & Rp3.157.706 & Rp2.040.054 & Rp1.151.701 & Rp0 & Rp0 \\
\hline 2 & Rp11.464.723 & Rp9.789.441 & Rp8.371.341 & Rp6.152.058 & Rp5.288.366 \\
\hline 3 & Rp19.854.744 & Rp17.654.199 & Rp15.733.746 & Rp12.582.115 & Rp11.288.991 \\
\hline 4 & Rp28.333.162 & Rp25.640.658 & Rp23.246.398 & Rp19.206.721 & Rp17.500.665 \\
\hline 5 & Rp36.900.034 & Rp33.749.794 & Rp30.911.430 & Rp26.030.788 & Rp23.929.820 \\
\hline 6 & Rp45.552.596 & Rp41.979.699 & Rp38.728.043 & Rp33.056.273 & Rp30.579.957 \\
\hline 7 & Rp54.290.311 & Rp50.330.701 & Rp46.697.698 & Rp40.287. & Rp37.456.986 \\
\hline 8 & Rp63.113.188 & Rp58.803.673 & Rp54.822.414 & Rp47.729.336 & Rp44.567.516 \\
\hline 9 & Rp72.021.797 & Rp67.400.055 & Rp63.104.795 & Rp55.387. & Rp51.918.912 \\
\hline 10 & Rp81.010.138 & Rp76.114.441 & Rp71.540.356 & Rp63.259.992 & Rp59.510.918 \\
\hline 11 & Rp90.076.554 & Rp84.945.810 & Rp80.129.040 & Rp71.349.611 & Rp67.347.910 \\
\hline 12 & Rp99.224.097 & Rp93.897.999 & Rp88.875.806 & Rp79.664.351 & Rp75.439.794 \\
\hline 13 & Rp108.458.594 & Rp102.977.783 & Rp97.788.714 & Rp88.215. & Rp83.800.150 \\
\hline 14 & Rp117.786.306 & Rp112.192.452 & Rp106.876.436 & Rp97.016.060 & Rp92.443.586 \\
\hline 15 & Rp127.210.310 & Rp121.545.915 & Rp116.144.098 & Rp106.073.984 & Rp101.380.879 \\
\hline 16 & Rp136.733.636 & Rp131.041.934 & Rp125.596.596 & Rp115.397.762 & Rp110.622.502 \\
\hline 17 & Rp146.362.621 & Rp140.687.717 & Rp135.242.424 & Rp124.999.626 & Rp120.183.087 \\
\hline 18 & Rp156.107.074 & Rp150.494.188 & Rp145.094.045 & Rp134.896.326 & Rp130.082.106 \\
\hline 19 & Rp165.978.600 & Rp160.474.178 & Rp155.165.958 & Rp145.107.010 & Rp140.341.656 \\
\hline 20 & Rp173.954,330 & Rp169.193.997 & Rp164.574.888 & Rp155.741.954 & Rp151.519.417 \\
\hline 21 & Rp.177.810.424 & Rp173.289.558 & Rp168.900.000 & Rp160.497.258 & Rp156.475.718 \\
\hline 22 & Rp185.924.263 & Rp182.224.004 & Rp178.613.258 & Rp171.650.021 & Rp168.292.603 \\
\hline 23 & Rp194.185.404 & Rp191.363.134 & Rp188.595.712 & Rp183.220.133 & Rp180.609.434 \\
\hline 24 & Rp196.083.575 & Rp194.168.538 & Rp192.281.536 & Rp188.589.466 & Rp186.783.348 \\
\hline 25 & Rp200.000.000 & Rp200.000.000 & Rp200.000.000 & Rp200.000.000 & Rp200.000.000 \\
\hline
\end{tabular}

Berdasarkan Tabel 3 pada tahun pertama untuk tingkat suku bunga 3\% dan 5\% nilai cadangan bernilai Rp0,- dikarenakan pada tahun tersebut premi yang dibayarkan oleh pihak tertanggung digunakan perusahaan untuk biaya oprasional. Pada tahun kedua dan seterusnya nilai cadangan yang 
diperoleh semakin meningkat hal tersebut menunjukan bahwa semakin besar tingkat suku bunga bebas risiko, maka nilai cadangan premi juga semakin murah.

\section{PENUTUP}

Perhitungan cadangan premi menggunakan metode Illinois pada tahun pertama menghasilkan cadangan premi sebesar Rp451.799,- dan cadangan premi akan meningkat untuk setiap tahunnya sehingga pada masa pertanggungan berakhir perusahaan asuransi telah siap untuk memberikan santunan sebesar yang dijanjikan kepada pemegang polis. Jika nilai tingkat suku bunga yang digunakan akan semakin besar, maka nilai cadangan semakin murah. Hal ini dikarenakan tingkat suku bunga bebas risiko merupakan variabel diskonto. Jika semakin besar tingkat suku bunga bebas risiko, maka semakin kecil nilai dari fungsi diskonto.

\section{DAFTAR PUSTAKA}

[1]. Futami, T. Matematika Asuransi Jiwa Bagian I. Tokyo: Incorporated Foundation Oriental Life Insurance Cultural Development Center;1993.

[2]. Bowers, N. L., Geerber, H. U., Hickman, J. C., Jones, D. A., \& Nesbitt, C. J. Actuarial Mathematics. Schaumhurg: Society Of Actuaries;1997.

[3]. Kellison, S. Theory of Interest, Edisi ke-7. New York: Mc.Graw Hill;1991.

[4]. Achdijad, Didi. Prinsip-Prinsip Aktuaria pada Asuransi Jiwa. Jakarta: Gunadarma;1990.

[5]. Salim A. Abbas. Asuransi dan Manajeman Resiko. Jakarta: Grafindo Persada;2007.

[6]. Effendie, A. R. Matematika Aktuaria. Jakarta: Universitas Terbuka;2010.

IRMA FRIYANTI

NEVA SATYAHADEWI

HENDRA PERDANA
: Jurusan Matematika FMIPA UNTAN, Pontianak irmafriyanti@student.untan.ac.id

: Jurusan Matematika FMIPA UNTAN, Pontianak neva.satya@math.untan.ac.id

: Jurusan Matematika FMIPA UNTAN, Pontianak hendra.perdana@math.untan.ac.id 